\title{
Preliminary Studies On Production And Partial Purification Of Toxins Associated With Black Tar Disease Of Yam (Dioscorea Species) In Makurdi, Benue State, Nigeria.
}

\author{
Bem, A.A. ${ }^{1}$ Terna, T.P. ${ }^{1}$, Iyoula, F.I. ${ }^{2}$, Waya, J.I. ${ }^{2}$, Orpin, J.B. ${ }^{1}$ and Manir, N. ${ }^{1}$ \\ ${ }^{I}$ Department of Biological Sciences, Federal University, Dutsin - Ma, PMB 5001, Dutsin-Ma, Katsina State. \\ ${ }^{2}$ Department of Biological Sciences, Benue State University, PMB 102119, Makurdi, Benue State, Nigeria.
}

\begin{abstract}
Studies were carried out to identify pathogens and toxins associated with the black tar disease of yam foliage (Yam anthracnose) in Makurdi, Benue State, Nigeria. Infected yam leaves and stems showing symptoms were collected from farms and cultured for isolation of causal organisms. Pure cultures of isolates were obtained using single spore method. Toxin extractions were done using $100 \mathrm{ml}$ of ethyl acetate in separating funnels. These were dried using a vacuum rotator evaporator. Partial purification of the toxin was done with the use of thin layer chromatography (TLC) plates. Results showed the predominant presence of Colletotrichum gloeosporioides. TLC quantification in four solvent systems suggests that the toxin produced is a glycoprotein.
\end{abstract}

Keywords: Black tar disease of yam, Colletotrichum gloeosporioides, Glycoprotein, TLC (Thin Layer Chromatography), Toxins.

\section{Introduction}

Yam (Dioscorea spp.) has been identified as an important staple food for millions of people worldwide [1]. It has been estimated that out of the world's production of over 30 million tones of yams, an average of over $25 \%$ of the yield is lost annually to disease and pest $[2,1]$, particularly anthracnose or black tar disease, which exerts a devastating impact on its productivity [3]. Bailey and Jegger [4] and Joseph et al. [5] reported that, black tar disease affecting yam foliage is one of the most important yam diseases with a worldwide distribution, found mainly in the subtropical and tropical regions of the world. Organisms causing this disease are facultative parasites known to produce metabolic substances (toxins) causing disease of plants generally referred to as anthracnose on a wide range of economically important plant crops including yam [5,6,7].

In several places where yam is cultivated, the disease has been reported to have infected and caused varying degrees of leaf necrosis and vines die back, resulting to a reduction in the effective photosynthetic surface area of the crop and consequently a reduction in the ability of the yam tuber to store food reserves [1]. Black tar disease of yam is therefore a major constraint to yam production [8].This study will provide base line information on yam black tar pathology in the study area, where yam is a major staple food crop. The study will enhance on-going efforts by farmers towards effective management of the disease.

\subsection{Collection of samples}

\section{Materials and Methods}

Portions of yam plants showing typical black tar symptoms were collected from three different farm lands in Makurdi, Benue State, Nigeria, in sterile polyethene bags and taken to the Botany Laboratory of Benue State University for further study.

\subsection{Preparation of samples}

Samples of infected leaves and vines of yam plants showing black tar symptoms were cut into smaller pieces using a sterile scapel. Cut tissues were then surface sterilized by immersion in $5 \% \mathrm{w} / \mathrm{v}$ sodium hypochlorite for $2 \mathrm{mins}$, after which the pieces were rinsed in distil water and blotted dry with sterile filter paper.

\subsection{Isolation and identification of disease pathogen}

Cut pieces of sampled plant tissues were plated on solidified PDA (Potato Dextrose Agar) in petridishes using a pair of sterile forceps, and incubated at $28^{\circ} \mathrm{C}$ for $4-7$ days in accordance with Ayodele et al. [9]. Identification of isolates in pure cultures was done by observing cultural and microscopic features as illustrated by Joseph et al. [5], Sutton [10] and Terna [11]. 


\subsection{Preparation of media for toxin production}

The liquid media used was prepared as illustrated by Bem et al. [12] and Chimbekujwo [13] as follows (in grams per 1.5 liters of distil water): peptone, 3 ; potassium dehydrogenate phosphate, 3 ; yeast extract, 0.2 ; ammonium chloride, 3; magnesium sulphate, 3; malt extract, 3. Sterilization of the media was done by autoclaving at $121^{\circ} \mathrm{C}$ and a pressure of 105 pa for $15 \mathrm{mins}$, and allowed to cool to about $46^{\circ} \mathrm{C}$, after which $40 \mathrm{mls}$ each were dispensed into sterile Mc Cartney bottles. Each bottle containing the media was inoculated with a loop full of mycelia harvested from 10 day old cultures using a sterile wire loop, and incubated at $25^{\circ} \mathrm{C}-28^{\circ} \mathrm{C}$ for 2 weeks without shaking as employed by Chmbekujwo [13]. This was carried out in triplicates with a control media in which mycelia of the pathogen were not introduced.

\subsection{Extraction of culture filtrate}

The cultures were filtered using Whatman No. 1 filter paper. Filtered mycelia mats were discarded appropriately, after which the $\mathrm{pH}$ of the culture supernatants were adjusted to 4 and extraction carried out using $80 \mathrm{mls}$ of ethylacetate for 30minutes. The extract was dried with anhydrous sodium thiosulphate and concentrated by evaporation on a vacuum rotary evaporator. The sample was then dissolved in ethanol and stored in a refrigerator until required as illustrated by Yoshida et al. [14]; Senyuva et al. [15] and Chimbekujwo [13].

\subsection{Partial purification of the toxin}

The solvent phases used were:

Solvent System 1: Ethanol/Acetic acid/Chloroform (ratio 1:1:3).

Solvent System 2: Ethanol/Acetic acid (ratio 2:1).

Solvent System 3: Ethylacetate/Chloroform/Petroleun ether (ratio 4:4:4)

Solvent System 4: Ethylacetate/Chloroform/Ethanol.

The solvent systems were developed in four separate tanks, TLC (Thin Layer Chromatography) plates labeled accordingly with a pencil and the solvent fronts measured. Each point to be spotted was also labeled. The labeled points on the TLC plates were spotted with the toxin extract and placed in different TLC tanks. The plates were developed in iodine tank and the mobile phases were marked. Various bands indicating the distance travelled by the sample were measured. The relative mobility of the spots was then calculated as shown in Eq. (1):

$\mathrm{RF}=\underline{\text { Distance moved by substance }}$

Distance moved by the solvent front.

Where RF $=$ Relative Mobility of the spots.

\section{Results}

Table 1. Cultural characteristics of the isolated pathogen.

\begin{tabular}{llllll}
\hline Growth on PDA & $\begin{array}{l}\text { Growth } \\
\text { Temp }{ }^{\circ} \mathrm{C}\end{array}$ & Mycelia colour & Spore type & Setae & Hyphae \\
\hline Rapid & $28 \pm 2^{\circ} \mathrm{C}$ & $\begin{array}{l}\text { Dark gray } \\
\text { colour }\end{array}$ & Conidia & Absent & Septate \\
\hline
\end{tabular}

TABLE 1 shows the cultural characteristics of the pathogen after 4 days of incubation. It was observed that at the growth temperature of $28 \pm 2^{\circ} \mathrm{C}$ the fungus grew rapidly on potato dextrose agar media (PDA), producing a whitish-wooly mycelia growth which gradually changed from white on day 4 to dark gray and finally black on day 10 (Fig. 1). Microconidia were also present (Fig. 2) and mycelia were found to be septate (Fig. 3). The fungus was further identified as $C$. gloeosporioides. 


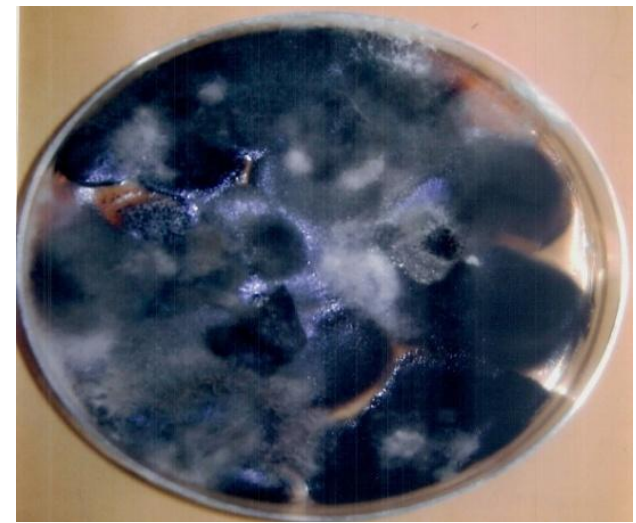

Figure 1. Culture of infected yam leaves on PDA after 10 of incubation days.

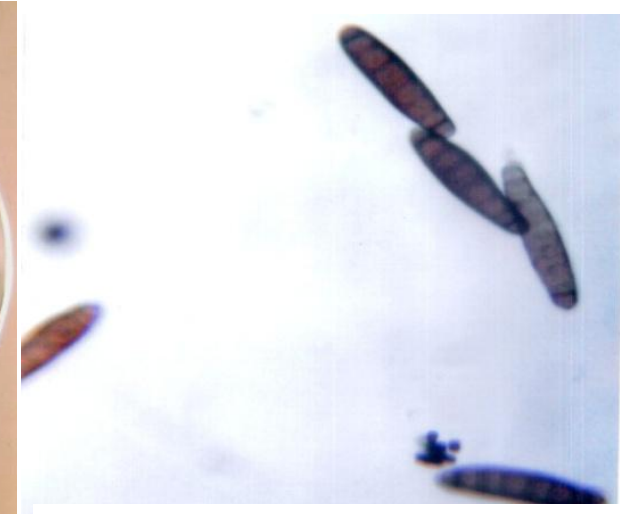

Figure 2. Straight, cylindrical microconidia of $C$. gloeosporioides.

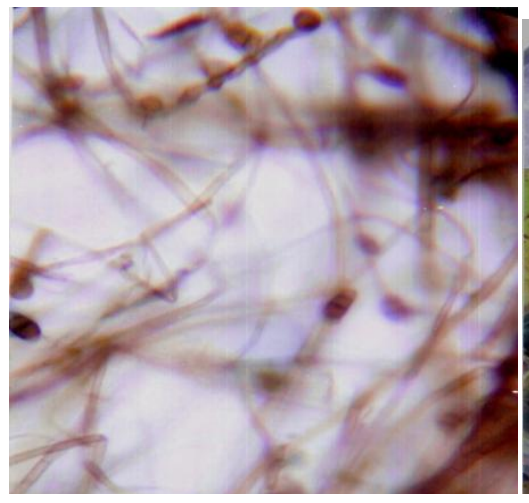

Figure 3. Septate hypha of C. gloeosporioides

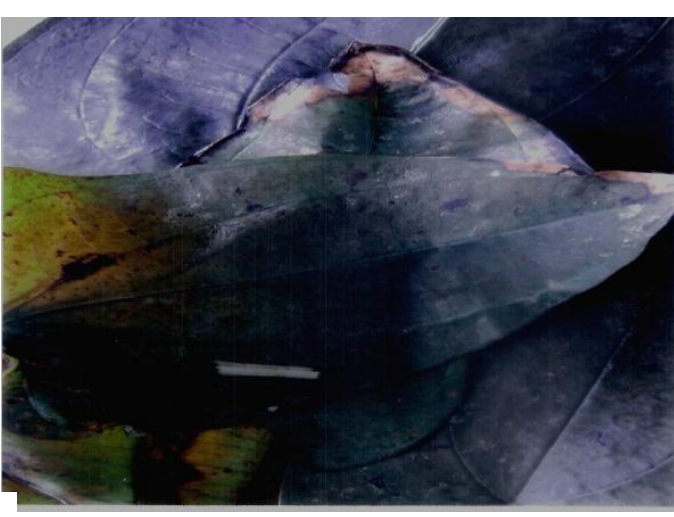

Figure 4. Yam leaf samples showing signs of black tar disease.

Fig. 4 is a pictograph of infected yam (Dioscorea spp.) plant showing typical signs of black tar disease, namely; regular spots with yellow halo, large regular brown spots with yellow halo, irregular brown spots with yellow halo and lastly, brown spots with concentric rings and a gray centre.

Table 2. Fungi isolated from different parts of diseased yam plants.

\begin{tabular}{ll}
\hline Plant part & fungi isolated \\
\hline Leaves & $\begin{array}{l}\text { Colletotrichum gloesporides } \\
\text { Aspergillus niger } \\
\text { Erysiphale spp. }\end{array}$ \\
& $\begin{array}{l}\text { Colletotrichum gloesporides } \\
\text { Aspergillus niger }\end{array}$ \\
Vinems & Colletotrichum gloesporides \\
& Erysiphale spp. \\
\hline
\end{tabular}

TABLE 2 shows the result of fungal isolations from different parts of the studied plant (Dioscorea sp.). The result revealed that although other fungal organisms were also present on the diseased plant parts, the occurrence of Colletotrichum gloesporides was highest as it was found on virtually every tissue sampled. 
Table 3. RF values of toxin extracts in four solvent systems on TLC plates.

\begin{tabular}{ll}
\hline Solvent system & RF value \\
\hline Ethanol/Acetic acid & $0.47-0.7$ \\
& \\
Ethanol/Acetic acid/Chloroform & $0.50-0.95$ \\
Ethylacetate/Chloroform/Petroleum ether & $0.38-0.76$ \\
Ethylacetate/Chloroform/Ethanol. & $0.30-0.86$ \\
\hline
\end{tabular}

TABLE 3 is a representation of the results of the calculation of relative mobility of toxins produced by the pathogen in four solvent systems. The solvent system involving ethanol/acetic acid /chloroform gave a higher $\mathrm{RF}$ value range $(0.50-0.95)$ followed by Ethanol/Acetic acid $(0.47-0.7)$.

\section{Discussion}

Cultural and morphological characteristics of the most frequently occurring fungus on diseased plant portions showed that the organism was $C$. gloeosporioides. A similar observation was reported by Ayodele $e t$ al. [9] who noted rightly that colonies of $C$. gloeosporioides are easily identified by their dark gray mycelia, and submerged sporulation with superficial patches of white fluffy growth. The presence of cylindrical conidia on hyphae of the suspected pathogen was also in agreement with the work of Joseph et al. [5] who reported that conidia of $C$. gloeosporioides are different from those of any known pathogenic species, in that conidia are straight, cylindrical and about $25 \mu \mathrm{m}$ by $4-6 \mu \mathrm{m}$ long. Green and Simons [16], Akem [3], and Abang [17] also isolated and recognized C. gloeosporioides as the major pathogen of yam dieback and necrosis, from leaves, stems, tubers and botanic seeds of yam in some parts of Nigeria. Yam infection by this pathogen has been found to affect photosynthetic activities leading to yield loses [1].

The role of phytotoxic metabolites in disease production by Colletotrichum species cannot be overemphasized. According to reports by Garcia-Pajon and Collado [18], Amusa [19], and Liyanage et al. [20], metabolites are employed in the breakdown of plant defences as evidenced by the death of tissues from which specific pathogens have been isolated. The major toxins isolated in the Study were identified as glycoproteins. This is similar to the work of Linde et al. [21] who worked on potential screening aid for selecting anthracnose substance in cucumbers using thin layer chromatography (TLC). A similar work was also reported by Alleyne et al. [22] in their studies on potential screening aid for selecting anthracnose substance in cucumbers and host selectivity of a 40kDa phytotoxic extract from C. gloeosporioides on yam (Dioscorea alata), respectively.

\section{Conclusion}

The ability of the suspected pathogen $(C$. gloeosporioides) to synthesize toxins of varying mobilities indicates the probable involvement of these moieties in symptom production in the studied area. Further studies will involve further purification and pathogenicity tests of purified toxins on healthy yam tissues.

\section{References}

[1] M.M. Abang, P. Hoffman, S. Winter, K.R. Green and G.A. Wolf, Vegetative compatibility among isolates of Colletotrichum gloeoesporioides from yam (Dioscorea spp) in Nigeria, Journal of phytopathology (2004) In press.

[2] FAO, Food and Agriculture Organization production year Book, Rome, 1998.

[3] C.N. Akem, Yam die-back and it's principal cause in the belt of Nigeria, Pakistan Journal of Biological Science 2, 1999 , $1106-1109$.

[4] J.A. Bailey, and M.J. Jegger, Colletotrichum biology pathology and control (Wallingford, United Kingdom: CAB International, 1992).

[5] C. Joseph, J. Guarro, and J. Gene, Molecular and Morphological identification of Colletotrichum species of clinical interest, Journal of Clinical Microbiology 42, 2004, 2450-2454.

[6] B.C. Sutton, The genus Glomerella and its anamorph Colletotrichum. Colletotrichum biology, pathology and control, in J.A. Bailey and M.J. Jeger (Eds.), CAB International, Wallingford, UK, 1992, pp. 1-26.

[7] M.M. Abang, S. Winter, K.R. Green, P. Hoffman, H.D. Mignouna and G.A. Wolf, Molecular identification of Colletotrichum gloeosporioides causing yam anthracnose in Nigeria, Plant Pathology, 51, 2002, 63-67.

[8] G.C. Orkwor and R. Asiedu, Yam research priorities, Tropical Root and Tuber Crops, Bulletin/IITA 8, $2004,11-13$.

[9] M.A. Ayodele, J. Hughes and R. Asiedu, Yam anthracnose disease: field symptoms and laboratory diagnostics (Ibadan: International Institute of Tropical Agriculture, 2004).

[10] B.C. Sutton, The coelomycetes, Fungi imperfecti with pycnidia, acervuli and stromata (Surrey, UK: Common wealth mycological institute, 1980).

[11] T.P. Terna, Antifungal activity of Trichoderma species isolated from different locations Botany and Microbiology, University of Ibadan, Nigeria, 2010. 
[12] A.A. Bem, R.W. Anyam and O.S. Irigo, Pathogens and toxins associated with wiltingtomato (Lycopersicum esculentum L. Mill) in Makurdi, Biotropical Research International Journal, 2009, in press.

[13] I.B. Chimbekujwo, Toxin production by Fusarium solani from roots and wilt diseasedcotton, Nigeria Journal of Basic and Applied Sciences 8, 1999, 21-26.

[14] S. Yoshida, S. Hiradate, Y. Fujii and A. Shirata, Colletotrichum dermatium producesphytotoxins in anthracnose lesions of mulberry leaves, Phytopathology 90, 2000, 258-291.

[15] H.Z. Senyuva, J. Gilbert, S. Hutton, Rapid Analysis of Crude Fungal Extracts for Secondary Metabolites by LC/TOF-MS - A New Approach to Fungal Characterization, available online at: www.agilent.com/chem.

[16] K.R. Green and S.A. Simons, 'Dead skin' on yams (Dioscorea alata) caused by Colletotrichum gloeoesporioides, Plant Pathology, 43,1994, 1062-1065.

[17] M.M. Abang, S. Winter, H.D. Mignouna, K.R. Green, and R. Asiedu, Molecular taxonomic, epidemiological and population genetic approaches in understanding yam anthracnose disease, Africa journal of biotechnology, 2, 2003, 486-496.

[18] C.M. Garcia-pajon and I.G. Collado, Secondary metabolites from Colletotrichum species, Natural products reports, 20, 2003, 426-431.

[19] N.A. Amusa, Microbially produced phytotoxins in disease management, African Journal of Biotechnology 5, $2006,405-414$.

[20] H.D. Liyanage, W. Koller, R.T. McMillan and H.C. Kistler, Variation in cutinase from two populations of Colletotrichum gloeosporioides, Phytopathology 83, 1993, 113-16.

[21] D.C. Linde, J.M. Shively and B.B. Rhodes, Toxins: potential screening aid for selecting anthracnose resistance in cucumbers, Curcubit, genetics cooperative report 12, 1989, 9-10.

[22] A.T. Alleyne and L.W. O'gawo, Host selectivity of a 40kDa phytotoxic extract from Colletotrichum gloeosporioides and tissue culture of Dioscorea alata (yam), M.Phil. Thesis, University of the West Indies, Cave Hill Campus, Barbados, 2008. 